Jurnal Ilmu Budaya, Vol. 18, No. 2 Februari Tahun 2022

\title{
SUPERIORITAS BUDAYA ASING DI INSTITUT TEKNOLOGI BANDUNG
}

\author{
Naqisya Arifani ${ }^{1}$, Muhammad Duta Wibawa Mawardi ${ }^{2}$, Fiona Angelica Tjahjono ${ }^{3}$, \\ Elizabeth Michele ${ }^{4}$, Maynardo Pratama Soegianto ${ }^{5}$, Fathimah Afra Nailah Adma ${ }^{6}$, \\ Shelly Delfiani ${ }^{7}$, Amelia Rahma Putri ${ }^{8}$, Jesslyn Gracsella Rusli ${ }^{9}$, Richard Alexander \\ Fedora Yoshuara $^{10}$, Jeremy $^{11}$, Christian August ${ }^{12}$, Tarissa Cindy Fitrian ${ }^{13}$ \\ Institut Teknologi Bandung \\ 10120007@mahasiswa.itb.ac.id ${ }^{1}, 10120062 @$ mahasiswa.itb.ac.id $^{2}$, \\ 10120102@mahasiswa.itb.ac.id 3 ,10220004@mahasiswa.itb.ac.id ${ }^{4}$, \\ 10220063@mahasiswa.itb.ac.id ${ }^{5}$ 10820012@mahasiswa.itb.ac.id ${ }^{6}$, \\ 10820014@mahasiswa.itb.ac.id , 10820018@mahasiswa.itb.ac.id ${ }^{8}$, \\ 10820026@mahasiswa.itb.ac.id9,10820030@mahasiswa.itb.ac.id ${ }^{10}$, \\ 10820034@mahasiswa.itb.ac.id ${ }^{11}$, 10820047@mahasiswa.itb.ac.id ${ }^{12}$, \\ 12220055@mahasiswa.itb.ac.id ${ }^{13}$
}

\begin{abstract}
Xenocentrism is a phenomenon that has recently been embedded in people's lives, especially students, where they feel a culture-based tendency to value other cultures more than their own, which can manifest in various ways. In practice, xenocentrism can indirectly pose a threat to the identity and national integrity of the Indonesian nation. Therefore, this study was conducted to show the superiority of foreign cultures within the scope of the observed ITB students and how the decline of nationalism was seen from the implementation of foreign cultures within the scope of ITB students. The research method used in this research is descriptive research. The sample used is the students of the Bandung Institute of Technology with a total of 247 respondents. Respondent sampling method used is the method of convenience samples or accidental samples and also purposive. The benefit of this research is to build awareness of ITB students on the importance of respecting the nation's culture and fostering national integrity in the lives of ITB students. The results showed that the level of xenocentrism in ITB was not too high, although overall the level of xenocentrism in Indonesia was quite high.
\end{abstract}

Keywords: Xenocentrism, foreign culture, integrity, nationalism, student 
Jurnal Ilmu Budaya, Vol. 18, No. 2 Februari Tahun 2022

A. PENDAHULUAN

Perkembangan zaman

membawa banyak sekali perubahan dalam kehidupan berbangsa dan bernegara, khususnya di Indonesia. Kemerdekaan Indonesia pada 17 Agustus 1945 silam menjadi titik awal keberjalanan Indonesia sebagai suatu bangsa yang mandiri. Akan tetapi, dinamika kehidupan bernegara tampaknya tidak semudah yang dibayangkan. Perkembangan zaman yang berdampak pada terbukanya akses informasi mengakibatkan berbagai tantangan baru. Terbukanya arus informasi ini membuat masyarakat harus memilah informasi yang diterima agar tidak mudah terpengaruh, terutama dalam hal budaya. Salah satu hal yang perlu dihindari adalah munculnya rasa rendah diri terhadap budaya asing. Munculnya rasa inferior mengenai budaya lokal terhadap budaya asing belakangan sering terjadi di Indonesia, khususnya di media sosial. Sikap tersebut disebut xenosentrisme.

Xenosentrisme merupakan suatu sikap di mana seseorang meremehkan budaya sendiri dan sangat mementingkan budaya asing. Perasaan inferior terhadap budaya lokal harus dihindari agar keberagaman budaya yang dimiliki tetap terjaga dan menjadi suatu identitas kuat bagi bangsa Indonesia, bukan menjadi sebaliknya.

Dalam literatur dan penelitian mengenai xenosentrisme dijelaskan bahwa banyak dari masyarakat Indonesia mengaku mencintai produk dalam negeri, tetapi sedikit masyarakat Indonesia yang tertarik untuk membeli produk dalam negeri. Direktur Jenderal Perdagangan Dalam Negeri Kementerian Perdagangan, Sri Agustina mengungkapkan hasil riset yang dilakukan oleh Universitas Indonesia. Riset tersebut menunjukkan terdapat $91 \%$ responden yang menyatakan bangga akan produk Indonesia. Namun, di dalam survei yang sama hanya $34 \%$ responden yang mau membeli produk Indonesia (Tempo, 2013).

Beberapa penelitian tentang xenosentrisme di Indonesia dari beberapa 
Jurnal Ilmu Budaya, Vol. 18, No. 2 Februari Tahun 2022

studi literatur yang diteliti, menjelaskan bahwa masyarakat Indonesia memiliki xenosentrisme yang cukup tinggi. Sebagai penerus bangsa, mahasiswa harus memiliki rasa nasionalisme yang tinggi untuk bangsanya agar negara yang mereka tempati dapat mengalami kemajuan. Sayangnya, penelitian mengenai sikap xenosentrisme di kalangan mahasiswa ini masih sangat minim.

Penelitian yang digunakan dapat berupa wawancara, kuesioner, atau angket yang disebarkan kepada mahasiswa. Hal ini penting untuk diteliti karena tanpa disadari mahasiswa sendirilah yang menjadi penyebar sikap xenosentrisme kepada lingkungan sekitarnya. Maka dari itu, peneliti ingin mengetahui seberapa tinggi tingkat xenosentrisme di kalangan mahasiswa ITB dan mengetahui seberapa tinggi tingkat xenosentrisme di Indonesia menurut mahasiswa ITB.

Hasil studi ini diharapkan dapat menjadi gambaran bagi masyarakat Indonesia mengenai kondisi xenosentrisme di Indonesia, khususnya di kalangan mahasiswa Institut Teknologi Bandung. Dengan demikian, masyarakat Indonesia secara kolektif dapat mengevaluasi dirinya dan bersama-sama kembali memahami kekayaan budaya Indonesia sebagai identitas bangsa.

\section{B. METODE PENELITIAN}

Penelitian ini merupakan penelitian deskriptif yang melaporkan keadaan yang ada menurut kenyataannya. Penelitian deskriptif bertujuan untuk mengetahui sikap, pendapat (opini), dan keadaan (Sigit, 2003).

Populasi penelitian ini adalah mahasiswa Institut Teknologi Bandung. Sampel penelitian ini adalah mahasiswa Institut Teknologi Bandung sejumlah 247 responden dengan rincian 146 mahasiswa Fakultas Ilmu Pengetahuan Alam, 29 mahasiswa Fakultas Teknik Industri, 17 mahasiswa Sekolah Teknik Elektro dan Informatika, 11 mahasiswa Fakultas Teknik Pertambangan dan Perminyakan, 9 mahasiswa Fakultas Teknik Sipil dan Lingkungan, 7 mahasiswa Sekolah Arsitektur, Perencanaan dan 
Jurnal Ilmu Budaya, Vol. 18, No. 2 Februari Tahun 2022

Pengembangan Kebijakan ITB, 5 mahasiswa Fakultas Ilmu dan

Teknologi Kebumian ITB, 4 mahasiswa Fakultas Teknik Mesin dan Dirgantara, 4 mahasiswa Sekolah Farmasi, 4 mahasiswa Fakultas Seni Rupa dan Desain, dan 2 mahasiswa Sekolah Bisnis dan Manajemen.

Penarikan sampel dalam penelitian ini menggunakan metode convenience samples atau accidental samples untuk mendapatkan informasi penelitian secara acak (Churchill, 1999:502) dan purposive sesuai dengan kebutuhan penelitian. Responden kemudian menjadi sumber data primer yang diminta untuk mengisi self-administered questionnaire.

\section{HASIL DAN PEMBAHASAN}

\section{Hasil}

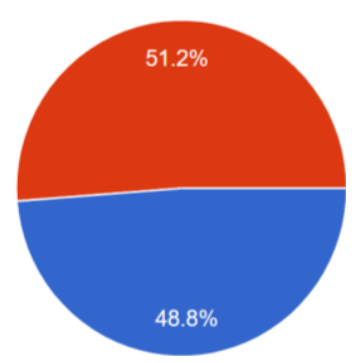

Grafik 1 Grafik Persentase Nama yang Cocok untuk Taman Wisata Impian Mahasiswa Institut Teknologi Bandung

Grafik di atas menggambarkan persentase nama yang cocok untuk taman wisata impian mahasiswa Institut Teknologi Bandung. Warna biru pada grafik merepresentasikan responden yang memilih Indonesia Wonderland sebagai nama yang cocok untuk taman wisata impian mereka. Warna merah pada grafik merepresentasikan responden yang memilih Taman Impian Indonesia sebagai nama yang cocok untuk taman wisata impian mereka. Berdasarkan survei yang telah dilakukan, diperoleh $48,8 \%$ responden yang memilih Indonesia Wonderland sebagai nama yang cocok untuk taman wisata impian mereka dan $51,2 \%$ responden yang memilih Taman Impian Indonesia sebagai nama yang cocok untuk taman wisata impian mereka. 


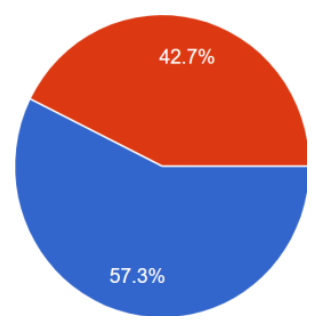

Grafik 2. Grafik Persentase Istana yang Cocok dibangun di Taman Wisata Impian Mahasiswa Institut Teknologi Bandung

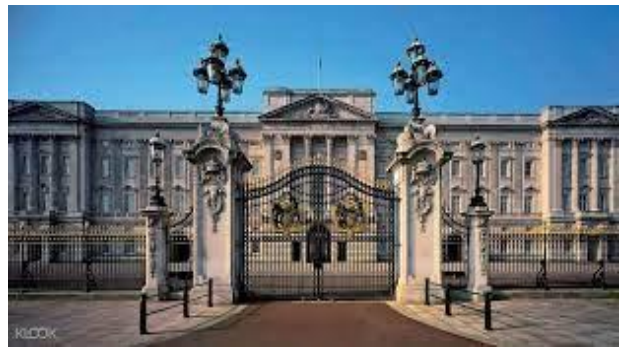

Gambar 1. Gambar untuk Pilihan 1 pada Grafik 2

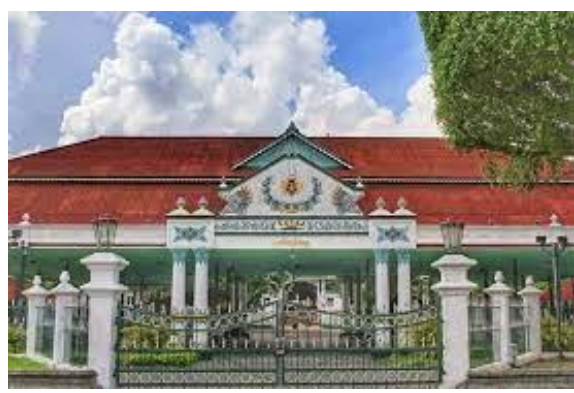

Gambar 2. Gambar untuk Pilihan 2 pada Grafik 2

Grafik di atas menggambarkan persentase istana yang cocok dibangun di taman wisata impian mahasiswa Institut Teknologi Bandung. Warna biru pada grafik merepresentasikan responden yang memilih Gambar 1 sebagai istana yang cocok dibangun di taman wisata impian mereka. Warna merah pada grafik merepresentasikan responden yang memilih Gambar 2 sebagai istana yang cocok dibangun di taman wisata impian mereka. Berdasarkan survei yang telah dilakukan, diperoleh $57,3 \%$ responden yang memilih Gambar 1 sebagai istana yang cocok dibangun di taman wisata impian mereka dan $42,7 \%$ responden yang memilih Gambar 2 sebagai istana yang cocok dibangun di taman wisata impian mereka.

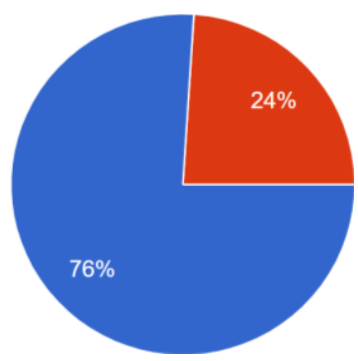

Grafik 3. Grafik Persentase Lagu yang Cocok diputar di Taman Wisata Impian Mahasiswa Institut Teknologi Bandung

Grafik di atas menggambarkan persentase lagu yang cocok diputar di taman wisata impian mahasiswa Institut Teknologi Bandung. Warna biru pada grafik merepresentasikan responden yang 
Jurnal Ilmu Budaya, Vol. 18, No. 2 Februari Tahun 2022

memilih lagu daerah Nusantara

sebagai lagu yang cocok diputar di taman wisata impian mereka. Warna merah pada grafik merepresentasikan responden yang memilih lagu klasik Eropa sebagai lagu yang cocok diputar di taman wisata impian mereka. Berdasarkan survei yang telah dilakukan, diperoleh $76 \%$ responden yang memilih lagu daerah Nusantara sebagai lagu yang cocok diputar di taman wisata impian mereka dan $24 \%$ responden yang memilih lagu klasik Eropa sebagai lagu yang cocok diputar di taman wisata impian mereka.

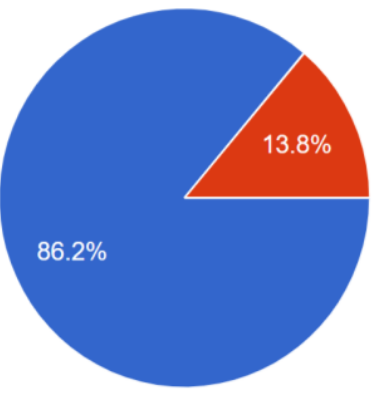

Grafik 4 Grafik Persentase Pertunjukan yang Cocok diadakan di Taman Wisata Impian Mahasiswa Institut Teknologi Bandung
Grafik di atas menggambarkan persentase pertunjukan yang cocok diadakan di taman wisata impian mahasiswa Institut Teknologi Bandung. Warna biru pada grafik merepresentasikan responden yang memilih pawai budaya Nusantara sebagai pertunjukan yang cocok diadakan di taman wisata impian mereka. Warna merah pada grafik merepresentasikan responden yang memilih Flash Mob sebagai pertunjukan yang cocok diadakan di taman wisata impian mereka. Berdasarkan survei yang telah dilakukan, diperoleh $86,2 \%$ responden yang memilih pawai budaya Nusantara sebagai pertunjukan yang cocok diadakan di taman wisata impian mereka dan $13,8 \%$ responden yang memilih Flash Mob sebagai pertunjukan yang cocok diadakan di taman wisata impian mereka.

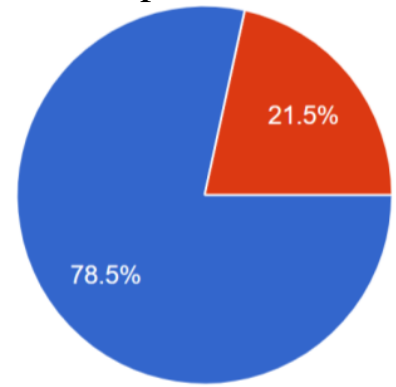

Grafik 5 Grafik Persentase Pakaian Unik yang akan disediakan di Photobooth 
Jurnal Ilmu Budaya, Vol. 18, No. 2 Februari Tahun 2022

Taman Wisata Impian Mahasiswa Institut Teknologi Bandung

Grafik di atas menggambarkan persentase pakaian unik yang akan disediakan di photobooth taman wisata impian mahasiswa Institut Teknologi Bandung. Warna biru pada grafik merepresentasikan responden yang memilih kebaya dan beskap sebagai pakaian unik yang akan disediakan di photobooth taman wisata impian mereka. Warna merah pada grafik merepresentasikan responden yang memilih jas dan gaun bangsawan Eropa sebagai pakaian unik yang akan disediakan di photobooth taman wisata impian mereka. Berdasarkan survei yang telah dilakukan, diperoleh $\quad 78,5 \%$ responden yang memilih kebaya dan beskap sebagai pakaian unik yang akan disediakan di photobooth taman wisata impian mereka dan $21,5 \%$ responden yang memilih jas dan gaun bangsawan Eropa sebagai pakaian unik yang akan disediakan di photobooth taman wisata impian mereka.

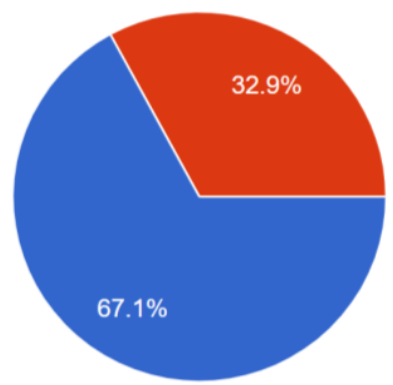

Grafik 6. Grafik Persentase Makanan Ringan yang akan dijual di Taman Wisata Impian Mahasiswa Institut Teknologi Bandung

Grafik di atas menggambarkan persentase makanan ringan yang akan dijual di taman wisata impian mahasiswa Institut Teknologi Bandung. Warna biru pada grafik merepresentasikan responden yang memilih baso tahu sebagai makanan ringan yang akan dijual di taman wisata impian mereka. Warna merah pada grafik merepresentasikan responden yang memilih dimsum sebagai makanan ringan yang akan dijual di taman wisata impian mereka. Berdasarkan survei yang telah dilakukan, diperoleh $67,1 \%$ responden yang memilih baso tahu sebagai makanan ringan yang akan dijual di taman wisata impian mereka dan 32,9\% responden yang memilih dimsum sebagai makanan 
ringan yang akan dijual di taman wisata impian mereka.

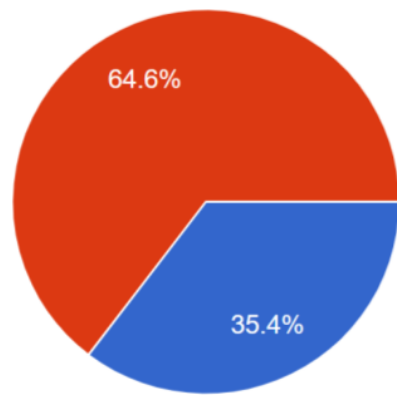

Grafik 7. Grafik Persentase Nama Menu Utama yang Cocok disajikan di Taman Wisata Impian Mahasiswa Institut Teknologi Bandung

\section{Grafik}

di atas menggambarkan persentase nama menu utama yang cocok disajikan di taman wisata impian mahasiswa Institut Teknologi Bandung. Warna biru pada grafik merepresentasikan responden yang memilih Beef Steak with Mushroom Sauce and Potato Wedges sebagai nama menu utama yang cocok disajikan di taman wisata impian mereka. Warna merah pada grafik merepresentasikan responden yang memilih daging panggang dengan saus jamur dan kentang goreng sebagai nama menu utama yang cocok disajikan di taman wisata impian mereka. Berdasarkan survei yang telah dilakukan, diperoleh $35,4 \%$ responden yang memilih Beef Steak with Mushroom Sauce and Potato Wedges sebagai nama menu utama yang cocok disajikan di taman wisata impian mereka dan $64,6 \%$ responden yang memilih daging panggang dengan saus jamur dan kentang goreng sebagai nama menu utama yang cocok disajikan di taman wisata impian mereka.

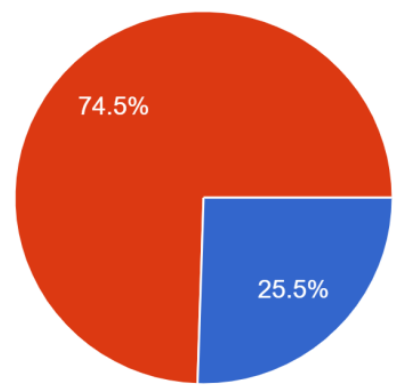

Grafik 8 Grafik Persentase Oleh-oleh yang akan disediakan/dijual di Taman

Wisata Impian Mahasiswa Institut Teknologi Bandung

Grafik di atas menggambarkan persentase oleh-oleh yang akan disediakan/dijual di taman wisata impian mahasiswa Institut Teknologi Bandung. Warna biru pada grafik merepresentasikan responden yang memilih cinderamata matruska doll 
Jurnal Ilmu Budaya, Vol. 18, No. 2 Februari Tahun 2022

(matryoshka), yaitu boneka khas

Rusia yang dapat diisi dengan bentuk boneka-boneka yang lebih kecil. Warna merah pada grafik merepresentasikan responden yang memilih mainan tradisional gasing kayu. Berdasarkan survei yang telah dilakukan, diperoleh $25.5 \%$ responden yang memilih matruska doll sebagai oleh-oleh yang akan disediakan/dijual di taman wisata impian mereka dan $74.5 \%$ responden yang memilih mainan tradisional gasing kayu sebagai oleh-oleh yang akan disediakan/dijual di taman wisata impian mereka.

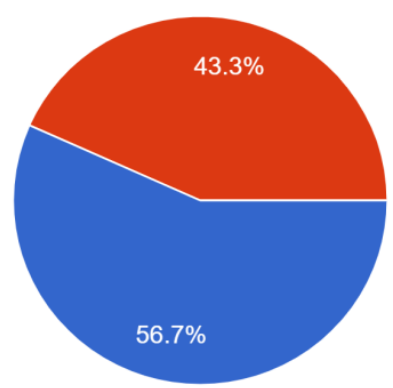

Grafik 9. Grafik Persentase

Mahasiswa Institut Teknologi Bandung yang Mengetahui Xenosentrisme

Grafik di atas menggambarkan persentase mahasiswa Institut Teknologi Bandung yang mengetahui xenosentrisme. Warna biru pada grafik merepresentasikan responden yang mengetahui xenosentrisme. Warna merah pada grafik merepresentasikan responden yang tidak mengetahui xenosentrisme. Berdasarkan survei yang telah dilakukan, diperoleh $56.7 \%$ responden yang mengetahui xenosentrisme dan $43.3 \%$ responden yang tidak mengetahui xenosentrisme.

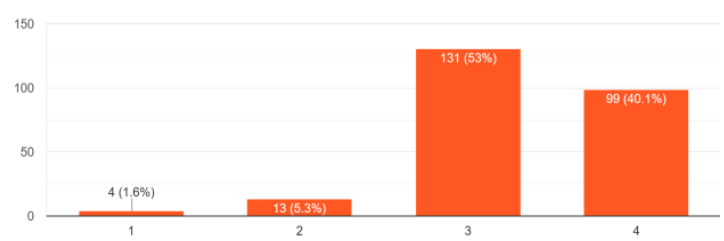

Grafik 10. Grafik Persentase Pendapat Mahasiswa Institut Teknologi Bandung terhadap Tingkat Xenosentrisme di Indonesia

Grafik di atas menggambarkan persentase pendapat mahasiswa Institut Teknologi Bandung terhadap tingkat xenosentrisme di Indonesia. Angka 1 merepresentasikan responden yang berpendapat bahwa tingkat xenosentrisme di Indonesia sangat rendah. Angka 2 merepresentasikan responden yang berpendapat bahwa tingkat xenosentrisme di Indonesia rendah. Angka 3 merepresentasikan responden yang 
Jurnal Ilmu Budaya, Vol. 18, No. 2 Februari Tahun 2022

berpendapat bahwa tingkat

xenosentrisme di Indonesia tinggi.

Angka 4 merepresentasikan

responden yang berpendapat bahwa

tingkat xenosentrisme di Indonesia

sangat tinggi. Berdasarkan survei

yang telah dilakukan, diperoleh

$1.6 \%$ responden yang berpendapat

bahwa tingkat xenosentrisme di

Indonesia sangat rendah, 5.3\%

responden yang berpendapat bahwa

tingkat xenosentrisme di Indonesia

rendah, 53\% yang berpendapat

bahwa tingkat xenosentrisme di

Indonesia tinggi, dan $40.1 \%$ yang

berpendapat bahwa tingkat

xenosentrisme di Indonesia sangat tinggi.

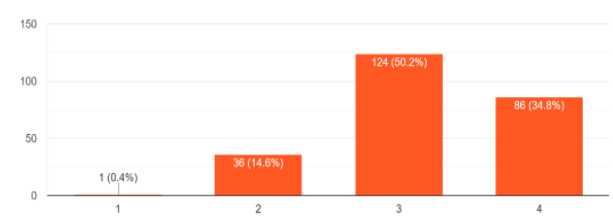

Grafik 11 Grafik Persentase

Pendapat Mahasiswa Institut

Teknologi Bandung terhadap

Tingkat Minat Masyarakat

Indonesia terhadap Budaya/Produk

Asing dibandingkan

Produk/Budaya Lokal
Grafik di atas menggambarkan persentase pendapat mahasiswa Institut Teknologi Bandung terhadap tingkat minat masyarakat Indonesia terhadap budaya/produk asing dibandingkan produk/budaya lokal. Angka 1 merepresentasikan responden yang berpendapat bahwa tingkat minat masyarakat Indonesia terhadap budaya/produk asing dibandingkan produk/budaya lokal sangat rendah. Angka 2 merepresentasikan responden yang berpendapat bahwa tingkat minat masyarakat Indonesia terhadap budaya/produk asing dibandingkan produk/budaya lokal rendah. Angka 3 merepresentasikan responden yang berpendapat bahwa tingkat minat masyarakat Indonesia terhadap budaya/produk asing dibandingkan produk/budaya lokal tinggi. Angka 4 merepresentasikan responden yang berpendapat bahwa tingkat minat masyarakat Indonesia terhadap budaya/produk asing dibandingkan produk/budaya lokal sangat tinggi. Berdasarkan survei yang telah dilakukan, diperoleh $0.4 \%$ responden yang 
Jurnal Ilmu Budaya, Vol. 18, No. 2 Februari Tahun 2022

berpendapat bahwa tingkat minat masyarakat Indonesia terhadap Grafik di atas menggambarkan budaya/produk asing dibandingkan produk/budaya lokal sangat rendah, $14.6 \%$ responden yang berpendapat bahwa tingkat minat masyarakat Indonesia terhadap budaya/produk asing dibandingkan produk/budaya lokal rendah, $50.2 \%$ yang berpendapat bahwa tingkat minat masyarakat Indonesia terhadap budaya/produk asing dibandingkan produk/budaya lokal tinggi, dan $34.8 \%$ yang berpendapat bahwa tingkat minat masyarakat Indonesia terhadap budaya/produk asing dibandingkan produk/budaya lokal sangat tinggi.

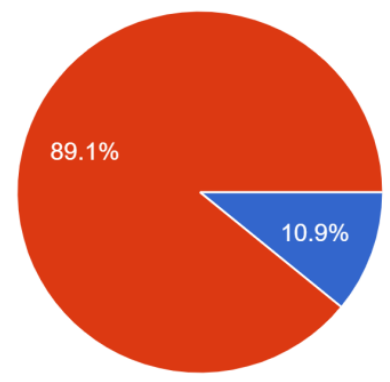

Grafik 12 Grafik Persentase Pendapat Mahasiswa Institut Teknologi Bandung terhadap Berkurangnya Rasa Nasionalisme dengan Membeli Produk Asing 
Jurnal Ilmu Budaya, Vol. 18, No. 2 Februari Tahun 2022

Grafik di atas menggambarkan persentase kepercayaan mahasiswa Institut Teknologi Bandung terhadap kualitas produk asing dan kualitas produk lokal. Warna biru pada grafik merepresentasikan responden yang lebih percaya pada kualitas produk asing. Warna merah pada grafik merepresentasikan responden yang lebih percaya pada kualitas produk lokal. Berdasarkan survei yang telah dilakukan, diperoleh $74.9 \%$ responden yang lebih percaya pada kualitas produk asing dan $25.1 \%$ responden yang lebih percaya pada kualitas produk lokal.

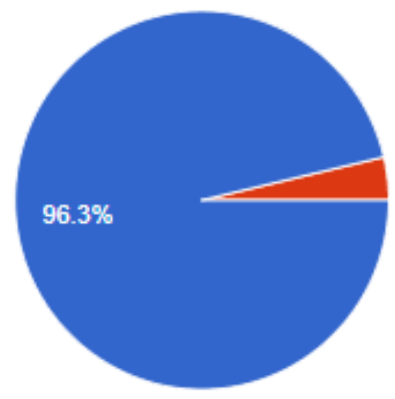

Grafik 14 Grafik Persentase Pendapat Mahasiswa Institut Teknologi Bandung Terhadap Kemampuan Produk Lokal Indonesia untuk Dapat Bersaing dengan Produk Asing
Grafik di atas menggambarkan persentase pendapat mahasiswa Institut Teknologi Bandung terhadap kemampuan produk lokal Indonesia untuk dapat bersaing dengan produk asing. Warna biru pada grafik merepresentasikan responden yang memilih jawaban "Iya", yang artinya mereka menganggap bahwa produk lokal Indonesia dapat bersaing dengan produk asing. Warna merah pada grafik merepresentasikan responden yang memilih jawaban "Tidak", yang artinya mereka menganggap bahwa produk lokal Indonesia tidak dapat bersaing dengan produk asing. Berdasarkan survei yang telah dilakukan, diperoleh 96,3\% responden memilih jawaban "Iya", yang artinya mereka menganggap bahwa produk lokal Indonesia dapat bersaing dengan produk asing. Sementara 3,7\% lainnya memilih jawaban "Tidak", yang artinya mereka menganggap bahwa produk lokal Indonesia tidak dapat bersaing dengan produk asing. 
Jurnal Ilmu Budaya, Vol. 18, No. 2 Februari Tahun 2022

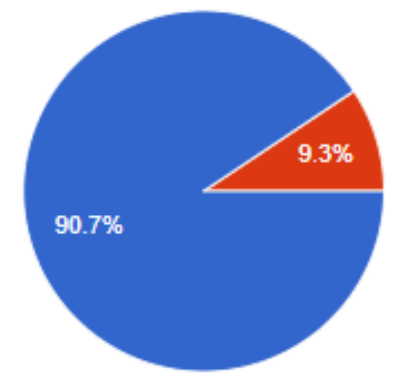

Grafik 15 Grafik Persentase

Pendapat Mahasiswa Institut Teknologi Bandung

Bahwa Pendidikan Membantu

Meningkatkan Pemahaman akan Budaya Indonesia

Grafik di atas menggambarkan persentase pendapat mahasiswa Institut Teknologi Bandung bahwa pendidikan membantu meningkatkan pemahaman akan budaya Indonesia. Warna biru pada grafik merepresentasikan responden yang memilih jawaban "Iya", yang artinya mereka menganggap bahwa pendidikan membantu meningkatkan pemahaman akan budaya Indonesia. Warna merah pada grafik merepresentasikan responden yang memilih jawaban "Tidak", yang artinya mereka menganggap bahwa pendidikan tidak membantu meningkatkan pemahaman akan budaya Indonesia.

Berdasarkan survei yang telah dilakukan, diperoleh $90,7 \%$ responden memilih jawaban "Iya", yang artinya mereka menganggap bahwa pendidikan membantu meningkatkan pemahaman akan budaya Indonesia. Sementara 9,3\% lainnya memilih jawaban "Tidak", yang artinya mereka menganggap bahwa pendidikan tidak membantu meningkatkan pemahaman akan budaya Indonesia.

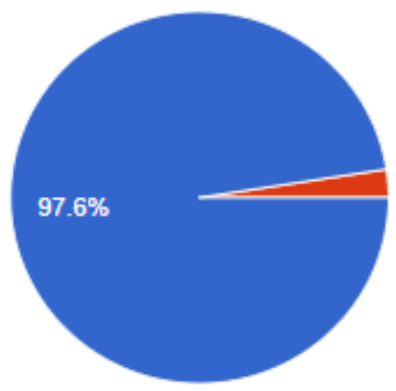

Grafik 16 Grafik Persentase Pendapat Mahasiswa Institut Teknologi Bandung Bahwa Indonesia Sedikit Tertinggal Jika

Dibandingkan dengan Negara Maju.

Grafik di atas menggambarkan persentase pendapat mahasiswa Institut Teknologi Bandung bahwa Indonesia sedikit tertinggal jika dibandingkan dengan negara maju. Warna biru pada grafik merepresentasikan responden yang memilih jawaban "Iya", yang artinya 
Jurnal Ilmu Budaya, Vol. 18, No. 2 Februari Tahun 2022

mereka menganggap bahwa

Grafik di atas menggambarkan

Indonesia sedikit tertinggal jika persentase pilihan mahasiswa Institut

dibandingkan dengan negara maju. Teknologi Bandung bahwa pernah Warna merah pada grafik terlintas di benak mereka untuk pindah merepresentasikan responden yang memilih jawaban "Tidak", yang artinya mereka menganggap bahwa Indonesia tidak tertinggal dengan negara maju. Berdasarkan survei yang telah dilakukan, diperoleh 97,6\% responden memilih jawaban "Iya", yang artinya mereka menganggap bahwa Indonesia sedikit tertinggal jika dibandingkan dengan negara maju. Sementara $2,4 \%$ lainnya memilih jawaban "Tidak", yang artinya mereka menganggap bahwa Indonesia tidak tertinggal dengan negara maju.

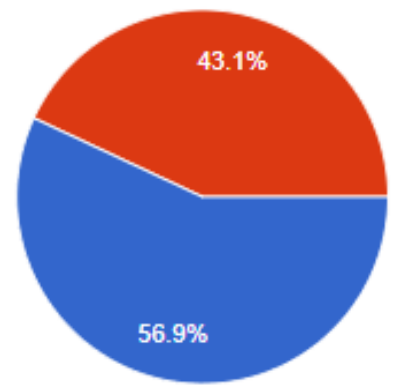
negara dari Indonesia. Warna biru pada grafik merepresentasikan responden yang memilih jawaban "Iya", yang artinya pernah terlintas di benak mereka untuk pindah negara dari Indonesia. Warna merah pada grafik merepresentasikan responden yang memilih jawaban "Tidak", yang artinya tidak pernah terlintas di benak mereka untuk pindah negara dari Indonesia. Berdasarkan survei yang telah dilakukan, diperoleh 56,9\% responden memilih jawaban "Iya", yang artinya pernah terlintas di benak mereka untuk pindah negara dari Indonesia. Sementara $43,1 \%$ lainnya memilih jawaban "Tidak", yang artinya tidak pernah terlintas di benak mereka untuk pindah negara dari Indonesia.

Grafik 17 Grafik Persentase Pilihan Mahasiswa Institut Teknologi Bandung Bahwa Pernah Terlintas di Benak Mereka untuk Pindah Negara dari Indonesia 


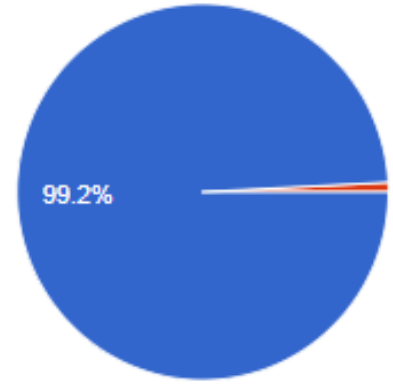

Grafik 18 Grafik Persentase Pendapat Mahasiswa Institut Teknologi Bandung Bahwa Perkembangan Teknologi Meningkatkan Kecepatan Penyebaran Budaya Asing di Indonesia

Grafik

di atas

menggambarkan persentase pendapat mahasiswa Institut Teknologi Bandung bahwa perkembangan teknologi meningkatkan kecepatan penyebaran budaya asing di Indonesia. Warna biru pada grafik merepresentasikan responden yang memilih jawaban "Iya", yang artinya mereka menganggap bahwa perkembangan teknologi meningkatkan kecepatan penyebaran budaya asing di Indonesia. Warna merah pada grafik merepresentasikan responden yang memilih jawaban "Tidak", yang artinya mereka menganggap bahwa perkembangan teknologi tidak meningkatkan kecepatan penyebaran budaya asing di Indonesia. Berdasarkan survei yang telah dilakukan, diperoleh 99,2\% responden memilih jawaban "Iya", yang artinya mereka menganggap bahwa perkembangan teknologi meningkatkan kecepatan penyebaran budaya asing di Indonesia. Sementara $0,8 \%$ lainnya memilih jawaban “Tidak", yang artinya mereka menganggap bahwa perkembangan teknologi tidak meningkatkan kecepatan penyebaran budaya asing di Indonesia.

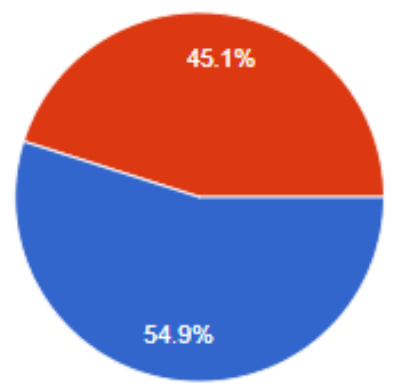

Grafik 19 Grafik Persentase Pendapat Mahasiswa Institut Teknologi Bandung Bahwa dengan Maraknya Budaya Asing yang ada di Indonesia (seperti KPOP, JPOP, dsb), Membuat Mereka Lebih Menikmati Budaya tersebut Dibanding Budaya Indonesia

Grafik di atas menggambarkan persentase pendapat mahasiswa Institut 
Jurnal Ilmu Budaya, Vol. 18, No. 2 Februari Tahun 2022

Teknologi Bandung bahwa dengan maraknya budaya asing yang ada di Indonesia (seperti KPOP, JPOP, dsb), membuat mereka lebih menikmati budaya tersebut dibanding budaya Indonesia. Warna biru pada grafik merepresentasikan responden yang memilih jawaban "Iya", yang artinya mereka menganggap bahwa dengan maraknya budaya asing yang ada di Indonesia (seperti KPOP, JPOP, dsb), membuat mereka lebih menikmati budaya tersebut dibanding budaya Indonesia. Warna merah pada grafik merepresentasikan responden yang memilih jawaban "Tidak", yang artinya mereka menganggap bahwa dengan maraknya budaya asing yang ada di Indonesia (seperti KPOP, JPOP, dsb), membuat mereka tidak lebih menikmati budaya tersebut dibanding budaya Indonesia. Berdasarkan survei yang telah dilakukan, diperoleh 54,9\% responden memilih jawaban "Iya", yang artinya mereka menganggap bahwa dengan maraknya budaya asing yang ada di Indonesia (seperti KPOP, JPOP, dsb), membuat mereka lebih menikmati budaya tersebut dibanding budaya Indonesia. Sementara 45,1\% lainnya memilih jawaban "Tidak", yang artinya mereka menganggap bahwa dengan maraknya budaya asing yang ada di Indonesia (seperti KPOP, JPOP, dsb), membuat mereka tidak lebih menikmati budaya tersebut dibanding budaya Indonesia.

\section{PEMBAHASAN}

Grafik 1 hingga grafik 8 merupakan hasil simulasi responden untuk membuat suatu taman wisata impian mereka. Berdasarkan hasil yang diperoleh, mayoritas responden memilih berbagai kombinasi budaya dan kearifan lokal Indonesia untuk diaplikasikan pada taman hiburan yang akan mereka ciptakan. Hal ini mengindikasikan bahwa sebagian besar responden memiliki kecintaan terhadap budaya dan kearifan lokal Indonesia, serta ingin untuk mempopulerkan budaya lokal tersebut 
Jurnal Ilmu Budaya, Vol. 18, No. 2 Februari Tahun 2022

dengan cara menerapkannya pada taman hiburan yang akan mereka buat.

Berdasarkan grafik 9 mengenai pengetahuan mahasiswa Institut Teknologi Bandung terhadap pengertian xenosentrisme, mayoritas responden mengetahui pengertian akan xenosentrisme itu sendiri. Sayangnya, jumlah responden yang mengerti akan xenosentrisme dengan yang tidak memang tidak terlalu jauh. Ini membuktikan kurangnya pengetahuan mahasiswa Institut Teknologi Bandung akan xenosentrisme. Padahal, xenosentrisme merupakan suatu fenomena yang kemungkinan besar mereka pernah ketahui, saksikan, atau bahkan alami sendiri. Dengan ketidahtahuan seseorang akan konsep atau pengertian xenosentrisme, secara tidak langsung ini mengimplikasikan ketidaksadaran mereka akan dampaknya ketika xenosentrisme itu sedang terjadi. Ketika xenosentrisme itu terjadi di sekitar mereka terlalu sering, mereka tidak mengetahui bahwa ini dapat menunjukkan suatu penyebab yang negatif seperti kurangnya rasa nasionalisme dan kepercayaan diri terhadap kewarganegaraanya sehingga dapat berdampak negatif. Dengan ini, masih cukup banyak kejadian bahwa seseorang tidak menyadari akan dampak buruk yang dapat ditimbulkan oleh xenosentrisme terhadap rasa nasionalisme seseorang.

Berdasarkan grafik 10 mengenai pendapat mahasiswa Institut Teknologi Bandung terhadap tingkat xenosentrisme di Indonesia, mayoritas responden berpendapat tingkat xenosentrisme di Indonesia berskala 3 dari 4. Bahkan, di atas $90 \%$ dari seluruh responden berpendapat tingkat xenosentrisme di Indonesia berskala 3 hingga 4 dari 4 sehingga hampir seluruh responden menganggap tingkat xenosentrisme itu sendiri di Indonesia cukup tinggi. Hasil ini jelas membuktikan bahwa para responden merasakan sendiri terjadinya xenosentrisme di Indonesia. Maka dari 
Jurnal Ilmu Budaya, Vol. 18, No. 2 Februari Tahun 2022

itu, secara umum, memang betul bahwa xenosentrisme terjadi di Indonesia secara nyata dan jelas.

Berdasarkan grafik 11 tentang pendapat mahasiswa Institut Teknologi Bandung terhadap tingkat minat masyarakat Indonesia terhadap budaya/produk asing dibandingkan produk/budaya lokal, mayoritas responden memiliki pendapat bahwasannya tingkat minat masyarakat Indonesia terhadap produk asing dibanding produk lokal berskala 3 dari 4 . Bahkan, menyentuh setengah jumlah responden dari seluruh responden yang ada untuk memilih skala 3 dari 4 tersebut. Hal ini membuktikan dan mendukung empat pernyataan berkenaan dengan perilaku konsumen pada negara-negara berkembang, salah satunya negara Indonesia, pertama bahwa konsumen cenderung memiliki persepsi nilai produk (perceived value) yang lebih tinggi pada produk-produk buatan asing dibandingkan produk buatan domestik (Ahmed and d'Astous, 2001), kedua bahwa konsumen merasa produk buatan negara-negara lebih maju dapat mengkomunikan status sosial dan kebanggan (Batra et al, 2000), ketiga bahwa konsumen dari negara berkembang juga biasanya tidak menyukai produk domestik karena memiliki pengalaman mengecewakan dengan produk domestik yang/berkualitas rendah (Nguyen et al, 2008, Lantz et al, 2002), dan keempat bahwa kepercayaan konsumen terhadap nilai produk atas sifat Consumer Xenocentrism tersebut berpengaruh terhadap perilaku pembelian konsumen pada produk domestik dan produk asing (Hsieh et al, 2004; Laroche et al, 2005, Orbaiz and Papadopoulos, 2003). Hasil responden yang tinggi ini juga selaras dengan peningkatan produk impor di Indonesia yang naik secara signifikan. Berdasarkan laman Badan Pusat Statistik, menurut golongan penggunaan barang, nilai impor terhadap barang konsumsi Indonesia dari kurun waktu enam bulan pertama di tahun 2021 naik 22,55 persen dibandingkan dengan tahun 2020 di periode yang sama, bahan baku/penolong 
Jurnal Ilmu Budaya, Vol. 18, No. 2 Februari Tahun 2022

yaitu 30,96 persen, dan barang

modal 19,68 persen.

Berdasarkan grafik 12

mengenai pendapat mahasiswa

Institut Teknologi Bandung

terhadap berkurangnya rasa

nasionalisme dengan membeli

produk asing, diperoleh hasil

mayoritas responden, yang

menyentuh angka $89,1 \%$ responden, berpendapat tidak setuju jika rasa nasionalisme berkurang dengan membeli produk asing. Dalam hal ini, hasil tidak membuktikan bahkan sangat bertolak belakang dengan pernyataan bahwa xenosentrisme menyebabkan masyarakat Indonesia cenderung terlalu mengagungkan negara asing sehingga merasa tidak puas dengan potensi negara sendiri. Dengan mayoritas pendapat yang tidak setuju, membuktikan bahwa mahasiswa ITB, dalam hal ini sebagai responden, masih memiliki rasa nasionalisme yang tinggi dan menjiwai paham dalam menganut kecintaan terhadap bangsanya.
Berdasarkan grafik 13 mengenai kepercayaan mahasiswa Institut Teknologi Bandung terhadap kualitas produk asing dan produk lokal, mayoritas responden lebih percaya terhadap kualitas produk lokal ketimbang dengan produk asing. Hal ini menunjukkan bahwasanya produk domestik memiliki nilai yang cukup tinggi daripada produk asing dikalangan mahasiswa Institut Teknologi Bandung. Selain itu, hal ini juga menunjukkan bahwa mahasiswa Institut Teknologi Bandung memiliki rasa nasionalisme yang cukup tinggi tergambar dari kecintaannya menggunakan, membeli, juga menyukai produk-produk buatan lokal karena dianggap memiliki kualitas yang lebih baik. Dengan mencintai produk dalam negeri, mahasiswa Institut Teknologi Bandung dapat dinyatakan telah turut berkontribusi dalam kegiatan berbela negara dalam bentuk non fisik.

Berdasarkan grafik 14 mengenai pendapat mahasiswa Institut Teknologi Bandung terhadap kemampuan produk lokal Indonesia untuk dapat bersaing dengan produk asing, mayoritas 
Jurnal Ilmu Budaya, Vol. 18, No. 2 Februari Tahun 2022

responden setuju bahwasanya

produk lokal di Indonesia dapat bersaing dengan produk asing terlihat dari hasil survey yang sangat tinggi bahkan persentasenya yang melebihi 90\%. Hal ini menunjukkan bahwa mayoritas responden memiliki optimisme yang sangat tinggi akan produk lokal yang ada di Indonesia. Hal ini juga dapat tampak pada keadaan saat ini, telah banyak influencer yang mulai mengajak atau memperkenalkan produk-produk buatan Indonesia dengan salah satu contohnya adalah produk skincare. Dapat dilihat bahwa produk skincare lokal di Indonesia memiliki perkembangan yang cukup pesat akhir-akhir ini. Produk ini juga tidak hanya meluas pada wilayah Indonesia, namun mengglobal mencapai luar negeri. Dengan demikian, pendapat mayoritas responden terbukti nyata terutama di kalangan mahasiswa Institut teknologi Bandung.
Berdasarkan grafik 15 mengenai pendapat mahasiswa Institut Teknologi Bandung terhadap pernyataan bahwa pendidikan membantu meningkatkan pemahaman akan budaya Indonesia, mayoritas responden setuju terhadap pernyataan tersebut. Hal ini berarti pada berbagai jenjang pendidikan yang telah dilalui oleh responden, mereka mendapatkan pendidikan mengenai budaya Indonesia. Pendidikan ini dapat berupa pengajaran khusus mengenai muatan lokal (bahasa daerah setempat maupun budaya lokal tempat sekolah didirikan). Pendidikan muatan lokal dapat meningkatkan kesadaran masyarakat akan pentingnya melestarikan budaya Indonesia dan mengembangkannya agar lebih mendunia melalui berbagai kreasi kontemporer anak bangsa.

Berdasarkan grafik 16 mengenai pendapat mahasiswa Institut Teknologi Bandung terhadap pernyataan bahwa Indonesia sedikit tertinggal jika dibandingkan dengan negara maju, mayoritas responden setuju terhadap pernyataan tersebut. Hal ini berarti sebagian besar responden menyadari akan 
Jurnal Ilmu Budaya, Vol. 18, No. 2 Februari Tahun 2022

majunya perkembangan teknologi

dan berbagai bidang lainnya secara global dan Indonesia sedikit tertinggal akan hal itu. Hal ini semakin terlihat jelas di masa pandemi saat ini, dengan tingkat kebutuhan gawai sangat meningkat tajam untuk pemenuhan pembelajaran dalam jaringan. Berbagai gawai yang digunakan masyarakat Indonesia merupakan produk luar negeri, seperti Samsung, Apple, Xiaomi, dan lain sebagainya. Gawai buatan dalam negeri, seperti Advan dan Axioo, masih jauh tertinggal dari gawai impor karena rasio harga dan teknologi yang ditawarkan mereka masih jauh lebih rendah dibandingkan gawai buatan luar negeri. Perangkat lunak yang digunakan pun merupakan perangkat lunak yang dikembangkan oleh industri teknologi luar negeri, seperti Google, Zoom, dan banyak lagi. Teknologi yang dikembangkan oleh Indonesia saat ini masih belum dapat bersaing dengan teknologi yang dikembangkan oleh perusahaan mancanegara.

Berdasarkan grafik 17 mengenai pilihan mahasiswa Institut Teknologi Bandung terhadap pilihan mereka untuk pindah negara dari Indonesia, mayoritas responden mengakui bahwa pernah terlintas di benak mereka untuk pindah dari negara Indonesia. Hal ini dapat menunjukkan bahwa sebagian besar dari mereka setuju bahwa kehidupan bermasyarakat di negara lain lebih baik dibandingkan taraf kehidupan di negara Indonesia. Selain itu, hal ini juga dapat menunjukkan bahwa di negara lain, lebih banyak hal yang menarik perhatian responden dibandingkan dengan hal-hal yang sering terjadi di Indonesia. Sebagai contoh, sudah banyak infrastruktur di negara-negara lain, khususnya negaranegara maju, yang memudahkan masyarakatnya untuk melakukan aktivitas sehari-hari, baik itu dalam bidang transportasi, informasi, hingga infrastruktur yang meningkatkan kesejahteraan masyarakatnya. 
Jurnal Ilmu Budaya, Vol. 18, No. 2 Februari Tahun 2022

Berdasarkan grafik 18 kerabatnya yang berada di negara lain mengenai pendapat mahasiswa hanya dengan satu sentuhan saja. Akan Institut Teknologi Bandung tetapi, ada pula bagian dari masyarakat terhadap perkembangan teknologi yang menolak masuknya perkembangan meningkatkan kecepatan teknologi ini. Menurut mereka, teknologi penyebaran budaya asing di Indonesia, hampir seluruh responden setuju terhadap pernyataan tersebut. Hal ini menunjukkan bahwa arus globalisasi yang membawa perkembangan baru dalam bidang teknologi cukup berpotensi untuk menggantikan budaya-budaya yang ada dengan budaya-budaya asing. Bagi sebagian besar masyarakat, masuknya teknologi-teknologi asing ini merupakan sebuah hal yang baik karena tidak dapat dipungkiri bahwa teknologiteknologi yang berasal dari negaranegara maju meningkatkan kemudahan masyarakat untuk melakukan hal-hal yang sebelumnya sulit untuk dilakukan. Sebagai contoh, dengan adanya telepon genggam masyarakat dapat dengan mudah mengabari dapat mempengaruhi aspek sosial dan budaya suatu kelompok masyarakat. Sebagai contoh, jika seseorang sudah merasa terlalu asyik dengan teknologi seperti di dunia maya, biasanya mereka akan menghabiskan waktu selama berjam-jam hanya untuk berinteraksi dengan seorang teman atau kenalan. Ketika teknologi berkembang semakin pesat permasalahan-permasalahan baru dalam bidang kebudayaan akan sulit untuk dihindari. Kebudayaan lokal akan semakin terkikis hanya karena masyarakatnya melupakan atau tidak mengindahkan adanya kebudayaan tersebut.

Berdasarkan grafik 19 mengenai pendapat mahasiswa Institut Teknologi Bandung terhadap maraknya budaya asing yang ada di Indonesia (KPOP, JPOP, dsb) yang membuat mereka menjadi lebih menikmati budaya tersebut dibanding budaya Indonesia, mayoritas 
Jurnal Ilmu Budaya, Vol. 18, No. 2 Februari Tahun 2022

responden mengakui bahwa mereka setuju akan pernyataan tersebut. Budaya asing, khususnya budaya pop Korea maupun Jepang, memiliki dampak yang sangat besar terhadap kebudayaan di Indonesia. Sudah banyak sektor-sektor di Indonesia termasuk cara berpakaian yang telah diinfiltrasi oleh budayabudaya asing ini. Bahkan, di kotakota besar seperti Jakarta, gaya hidup bebas yang merupakan gaya dari budaya-budaya luar sudah menjadi bagian dari kehidupan sehari-hari. Seorang pengelola sindikat siaran televisi Korea Selatan, Kim Song Hwan, menyebutkan bahwa produk budaya Korea berhasil menjangkau penggemar di semua kalangan terutama di Indonesia hanya dengan teknik pemaparannya yang disebut Asian Values-Hollywood Style. Sayangnya, Indonesia belum dapat menyaring dengan baik setiap pengaruh budaya asing yang masuk dan menyebabkan terjadinya ketimpangan dari segi kebudayaan.

\section{PENUTUP}

Berdasarkan hasil survei menunjukkan bahwa mahasiswa ITB memiliki tingkat nasionalisme yang tinggi. Sebagian besar berpendapat bahwa membeli produk asing tidak akan mengurangi rasa nasionalisme. Mereka juga setuju bahwa pendidikan membantu meningkatkan pemahaman akan budaya Indonesia karena pada jenjang pendidikan sebelumnya mereka mendapatkan pembelajaran akan budaya Indonesia. Pendidikan muatan lokal dapat meningkatkan kesadaran masyarakat akan pentingnya melestarikan budaya Indonesia dan mengembangkannya agar lebih mendunia melalui berbagai kreasi kontemporer anak bangsa. Mereka juga berpendapat produk domestik memiliki nilai yang cukup tinggi daripada produk asing dan optimis bahwa produk lokal Indonesia dapat bersaing dengan produk asing.

Dari hasil survei yang didapat, mayoritas mahasiswa Institut Teknologi Bandung (ITB) mengaku kurang memiliki pengetahuan akan xenosentrisme. Namun, dari sudut 
Jurnal Ilmu Budaya, Vol. 18, No. 2 Februari Tahun 2022

pandang mereka, tingkat tetapi dalam ruang lingkup mereka xenosentrisme di Indonesia cukup tingkat xenosentrisme tidak terlalu tinggi tinggi. Hal ini dibuktikan dari yang dibuktikan pada hasil survei yang sebagian besar responden didapat.

menyadari akan majunya perkembangan teknologi dan berrbagai bidang lainnya secara global sedangkan Indonesia sedikit tertinggal akan hal itu. Selain itu, kehidupan bermasyarakat di negara lain lebih baik dibandingkan taraf kehidupan di negara Indonesia. Arus globalisasi yang membawa perkembangan baru dalam bidang teknologi juga cukup berpotensi untuk menggantikan budaya lokal yang ada dengan budaya asing, khususnya budaya pop Korea maupun Jepang yang memiliki dampak cukup besar terhadap kebudayaan di Indonesia. Tingkat minat masyarakat Indonesia terhadap budaya/produk asing pun dinilai masih tinggi oleh mahasiswa ITB. Oleh karena itu, menurut mahasiswa ITB, Indonesia secara keseluruhan memiliki tingkat xenosentrisme yang cukup tinggi,

\section{Daftar Pustaka}

Churchill, G. A. 1999. "Marketing Research; Methodological Foundations, 7. bask1. Hanya 34 Persen Orang Indonesia Beli Produk Lokal". (2013, October 3). Tempo.Co. Diakses pada November 15, 2021.

Nasution, R. D. 2017. "Effect of the development of communication information technology on local cultural existence". Jurnal Penelitian Komunikasi Dan Opini Publik, 21(1).

Nguyen, D.T, Nguyen, T. T. M. and Barret, N. 2008. "Consumer ethnocentrism and xenocentrism, cultural sensitivity, and intention to purchase local product". Journal of Consumer Behavior, Vol. 7, pp.88100. 
Jurnal Ilmu Budaya, Vol. 18, No. 2 Februari Tahun 2022

Sigit, S. 1999. Pengantar

Metodologi Penelitian Sosial-

Bisnis-Manajemen. Jakarta:

Luckman Offset.

Yoga, S. 2019. Perubahan Sosial

Budaya Masyarakat

Indonesia dan Perkembangan

Teknologi Komunikasi. Jurnal

Al-Bayan: Media Kajian dan

Pengembangan Ilmu Dakwah, 24(1). 